\title{
Preliminary results of investigations related to the ecology of Urdari open-pit lake
}

\author{
Florin Faur $^{1 *}$, Izabela-Maria Apostu ${ }^{1}$, and Maria Lazăr ${ }^{1}$ \\ ${ }^{1}$ University of Petrosani, Department of Environmental Engineering and Geology, University Street, \\ no. 20, Petrosani, Romania
}

\begin{abstract}
Flooding the remaining gaps of lignite open-pits and the formation of so-called open-pit lakes tends to become an increasingly common practice in Romania (in the Oltenia Mining Basin, where the lignite deposit contained in Dacian and Romanian formations was and is extracted through open-pits). This type of ecological reconstruction of former exploitation areas has been applied worldwide for quite a time, and there are many references in this regard in the scientific literature. In this context, the present paper aims to present some preliminary results regarding the ecology of these lakes, being taken as case study the lake formed in the remaining gap of Urdari open-pit, within the Rovinari Mining Basin. However, given the multitude of similar conditions (bioclimate, geological framework, the formation of the remaining gaps, etc.) in which they form, we appreciate that the conclusions of this study can be extrapolated for other lakes in the area (eg. South Peșteana). We point out from the outset that this study presents data on the existing biotope and biocenoses (restricted to species identification), without going into details about populations, ecosystem production, energy and matter flows within it, these investigations being foreseen for a future development stage of the present study.
\end{abstract}

\section{Introduction}

Artificial lakes, resulting either from damming watercourses or by flooding of gaps resulting from excavations (made for this purpose or for the extraction of useful mineral substances), are often found all over the world and represent interesting study objectives for researchers from different fields (hydrologists, geochemists, environmental engineers, biologists, ecologists, etc.).

The lakes of the last category, those resulting from flooding the remaining gaps of some former quarries and open-pits, from which useful minerals were extracted, whether formed voluntarily or involuntarily, aroused the interest of researchers in several directions, such as: the geotechnical risks posed by these lakes to neighboring areas during and after flooding [1, 2]; the evolution of the basin from a morphological point of view [3-5], the influence of the rocks that make up the lake basin on the water chemistry; evolution of water quality $[3,6]$; evolution of vegetation and fauna installed spontaneously and/or by

* Corresponding author: faurfloring@yahoo.com 
human interventions [7-9]; their ecology, functionality and dynamics [8, 9]; usage possibilities for various purposes (recreational lakes, sport fishing, irrigation tanks, flood protection, etc.) [10-14]; influences on zonal hydrological regimes [15]; the influences exerted on the local microclimates, etc.

Urdari open-pit lake began to form at the end of 2003 - beginning of 2004, with the cessation of productive activities and the withdrawal of equipments from the open-pit of the same name, in the gap formed between the final slopes of the open-pit and those of the inner dump (Figure 1).

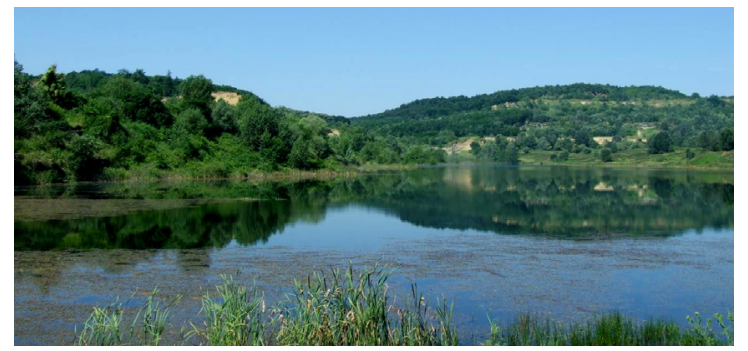

Fig. 1. Urdari open-pit lake in June 2021.

In other words, it is a young lake, which was little studied from an ecological point of view, at the level of $2010[10,16]$, thus representing an attractive objective for the authors. The research was resumed in 2019, and we appreciate that it can provide valuable information that can be extrapolated to other open-pit lakes in the Oltenia Mining Basin (existing, such as: Moi, Beterega and South Peşteana; or planned, such as: North Peșteana and Roșia de Jiu).

\section{Description of the biotope and physical conditions}

The former exploitation perimeter of Urdari open-pit is located in the southern area of the Rovinari Mining Basin (subdivision of Oltenia Mining Basin), on the territory of Urdari commune, Gorj county, $40 \mathrm{~km}$ south of Tg. Jiu city, respectively $15 \mathrm{~km}$ west of Ţicleni town, in a hilly area, west of the Jiu River.

The remaining gap of Urdari open-pit was formed as a result of the exploitation activity of lignite deposit from the Dacian and Romanian formations from Oltenia, through a continuous mining technology. In Urdari open-pit, layer no. X of lignite was mainly exploited, while layers no. XI and XII appeared sporadically in the upper exploitation tiers [17].

It is delimited as follows: to the north: by the inner dump of the open-pit; to the south: by Poduri Valley and Bujorului Glade; to the east: by Săscuia Valley; to the west: a hilly area with very rugged terrain (Figure 2).
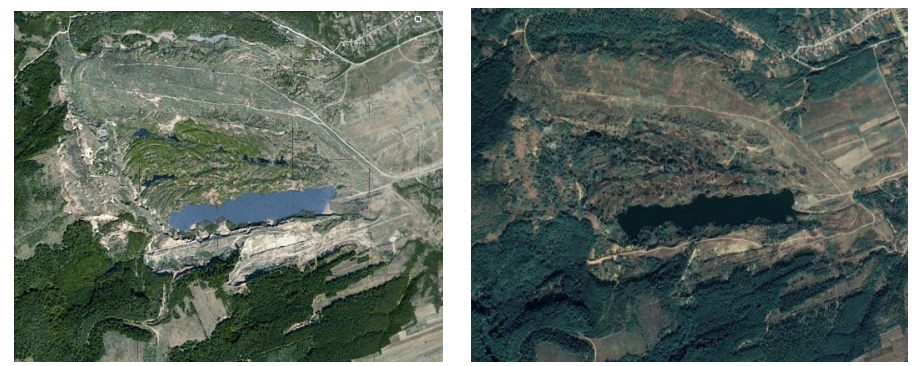

Fig. 2. Urdari open-pit lake, in 2010 (left), respective in 2019 (right). 
The remaining gap occupies approx. 19 ha, has an elevation at the bottom between +145 and $+152 \mathrm{~m}$, has a length of $950 \mathrm{~m}$, a maximum width of $220 \mathrm{~m}$, the elevation of the water level being at approx. $+165 \mathrm{~m}$ (maximum depth, of about $20 \mathrm{~m}$, being reached in the central-eastern part) $[10,16]$. In the excessively dry years, the water level dropped to approx. $+160 \mathrm{~m}$.

As can be seen from Figure 2, over time, the lake formed in the remaining gap has not undergone significant changes in terms of size and morphology. This is mainly due to factors related to the evolution of vegetation spontaneously installed on the final slopes of the open-pit and the inner dump and the arrangements existing since the active period of lignite exploitation:

1. The relatively rapid installation of grassy, shrubby and arboreal vegetation on the slopes prevented the occurrence of accentuated rain erosion, or even the triggering of landslides, which could have significantly changed the shape of the lake shores on the one hand, and on the other hand, it prevented the massive transport of disaggregated materials from these slopes, which could have led to the clogging of certain areas.

2. The existence, on the right side of the lake (east side), of a drainage channel. This channel initially had the role of directing the waters coming from the precipitations and from the aquifers intercepted by the mining works towards the Jiu River, so that the mining operations could be carried out in optimal conditions from the technical point of view and regarding the safety of the workplace. Currently, this channel ensures the drainage of excess water from rainfall and surface runoff from the slopes, thus maintaining a relatively constant level of water in the lake.

At the base, the lake basin is formed by the clay layer beneath the no. X lignite layer, thus favoring the accumulation of water in the remaining gap. The shores of the lake are formed as follows [16]:

- in the northern part by the slopes of the inner dump, which consist in a heterogeneous mixture of rocks: non-cohesive rocks (sands), about $12 \%$; weakly cohesive rocks (loamy dust, loamy-sandy dust, loamy sand, dusty sand), about $23 \%$; cohesive rocks (greasy clay, dusty-marly clay, marly clay), about $65 \%$, and fragments of coal (lignite);

- on the western and southern sides by the final slopes of the open-pit, made up of an alternation of clays and, on a variable thickness, the no. X layer of lignite. In the upper part, quite far above the lake, layers of sand and gravel (terrace deposits) can be observed;

- the eastern side is made up of the natural land present in the area.

The climate. From the analysis of the monthly averages of air temperatures recorded at the two nearest meteorological stations (Tg. Jiu and Apa Neagră) compared to the studied area, it was found that the coldest month of the year is January (average temperature being of $-2.5^{\circ} \mathrm{C}$ at both weather stations). The warmest month is July (average values between $20.6^{\circ} \mathrm{C}-21.4^{\circ} \mathrm{C}$ ) [10]. It should be noted that the average temperatures in December are positive, and the average annual temperatures range between $9.7^{\circ} \mathrm{C}$ and $10.6^{\circ} \mathrm{C}$.

In general, the highest monthly amounts of precipitation are recorded in late spring or early summer (May and June) or autumn, in October, and the multiannual average rainfall is of $762.81 \mathrm{l} / \mathrm{m}^{2}$.

Vegetation. The predominant vegetation in the areas surrounding Urdari open-pit is specific to the hilly area of Oltenia and includes deciduous forests. As tree species present in the area we mention beech (Fagus silvatica) and quercinea species (Qurcus petraea, Qurcus polycarpa, Quercus robur, Quercus cerris and Quercus frainetto).

Forest areas alternate with meadows and agricultural land. The representative crops are those of corn, cereals, potatoes, etc. On small areas there are orchards and vineyards.

Water temperature. In Urdari lake, heating is produced almost exclusively by the sun's rays, to which, with less influence, the heat radiated by the atmosphere and the shores is added. It is influenced by the circadian and seasonal rhythms. 
In Urdari lake there is a thermal stratification of the water, registering daily, monthly and annual thermal variations. The heat stored during the summer is gradually lost in autumn and winter. In summer, the water temperature at the surface of the lake varies between 20 and $25^{\circ} \mathrm{C}$, and decreases with depth, reaching at the bottom area up to $4^{\circ} \mathrm{C}$. This is the direct thermal stratification. The vertical decrease of the water temperature is done gradually and evenly to a certain depth where there is a sudden decrease. This level is called the thermal jump layer or metalimnion. The water layer above the metalimnion is called the epilimnion and the one below it is called the hypolimnion [18, 19].

In autumn, as the air cools, the water cools to the surface, becomes heavier and descends lower, its place being taken by the warmer and therefore lighter water that rises to the surface. The vertical current is accentuated and maintained until all the water in the basin has reached a temperature of $4^{\circ} \mathrm{C}$. Along with the thermal uniformization, the dissolved oxygen is uniformized. In winter, the water continues to cool to the surface to $0^{\circ} \mathrm{C}$, when the formation of ice crystals is favored. Under the formed ice bridge the temperature rises to the bottom reaching $+4^{\circ} \mathrm{C}$. This is the winter (reversed) thermal layering. In the spring, the water layers on the surface begin to heat up under the direct action of the sun's rays, becoming denser, descending to where they find the water layers with the same thermal value. In this way the thermal stratification of the water established during the winter breaks down. The process itself continues until the water reaches the same temperature $\left(+4^{\circ} \mathrm{C}\right)$, over its entire thickness. The thermal uniformization during spring is also supported by the wind. This is the so-called spring circulation [18].

Thermal stratification of water during summer and winter and the temperature uniformizations in autumn and spring are of great importance for the life of biocenoses.

The density and viscosity of lake water varies over the course of a year. The important factor that drives these characters is the temperature. The water has the highest density at $+4^{\circ} \mathrm{C}$, decreasing at temperatures above and below this value.

The viscosity of water is given by temperature, organic and inorganic suspensions. The viscosity of the water decreases with increasing temperature. In winter, the water being cold, with higher density and viscosity, allows a better floating of aquatic organisms [19].

The surface tension appears at the contact surface of the water with the air and has the property of a pseudo membrane. The value of surface tension is influenced by temperature, organic and inorganic suspensions as well as dissolved substances [18].

The transparency of the water of Urdari lake varies depending on the amount of organic and inorganic matter in suspension and the amount of dissolved substances, the light entering the water at different depths depending on its turbidity at a given time.

Water color. In Urdari lake the water is generally colorless, but at certain times of the year or in certain years (the dry ones), the water may have a slightly yellowish or greenish color. The cause of coloring is the organic or mineral suspensions and the exaggerated multiplication of algae, a phenomenon known as water flowering.

Horizontal currents in the case of Urdari lake are exclusively of wind origin. They move the mass of water to a greater or lesser thickness depending on their intensity and duration. Friction of the air on the water mirror produces waves and surface currents.

Water chemistry. The water quality of Urdari lake was not monitored over time, so, for the present study water samples were taken in order to determine their quality. The analyses were performed in the laboratory of Zănoaga Water Treatment Plant and in the chemistry laboratory of the University of Petroșani in 2019 [6]. Standard methods of sampling, transportation and analyses have been applied [20]. Table 1 shows the values of the main surface water quality indicators, compared to the existing standards [21].

As the water of Urdari lake comes in contact with coal remains in the dump or with the lignite layers from the in-situ slopes and the elementary chemical composition of lignite includes carbon, oxygen, hydrogen, nitrogen, and sulphur, there is a possibility for its 
acidification. However, the analyses performed on the water samples from Urdari open-pit lake do not confirm this hypothesis [6].

Table 1. Results of water quality analyses [6].

\begin{tabular}{|c|c|c|c|c|c|}
\hline \multirow{2}{*}{$\begin{array}{l}\text { Crt. } \\
\text { No. }\end{array}$} & \multirow[b]{2}{*}{ Quality indicator } & \multirow[b]{2}{*}{$\mathbf{U M}$} & \multicolumn{2}{|c|}{ Determined values } & \multirow{2}{*}{$\begin{array}{l}\text { II }^{\text {nd }} \text { quality class } \\
\text { (according to } \\
\text { Order } 161 / 2006)\end{array}$} \\
\hline & & & Urdari & $\begin{array}{c}\text { Times } \\
\text { over }\end{array}$ & \\
\hline 1 & $\mathrm{pH}$ & $\mathrm{pH}$ units & 8.00 & - & $6.5-8.5$ \\
\hline 2 & $\mathrm{CBO}_{5}$ & $\mathrm{mg} / \mathrm{l}$ & 5.10 & 0.02 & 5 \\
\hline 3 & $\mathrm{CCO}_{\mathrm{Cr}}$ & $\mathrm{mg} / \mathrm{l}$ & 14.10 & - & 25 \\
\hline 4 & Chlorides & $\mathrm{mg} / \mathrm{l}$ & 12.05 & - & 100 \\
\hline 5 & Sulphates & $\mathrm{mg} / \mathrm{l}$ & 22.84 & - & 150 \\
\hline 6 & Calcium & $\mathrm{mg} / \mathrm{l}$ & 112.40 & - & 150 \\
\hline 7 & Magnezium & $\mathrm{mg} / \mathrm{l}$ & 34.80 & 0.392 & 25 \\
\hline 8 & Phenols & $\mathrm{mg} / \mathrm{l}$ & 0.080 & 80 & 0.001 \\
\hline 9 & Iron & $\mathrm{mg} / \mathrm{l}$ & 0.108 & 0.08 & 0.1 \\
\hline 10 & Suspensions & $\mathrm{mg} / \mathrm{l}$ & 3.78 & - & - \\
\hline
\end{tabular}

The relative high concentrations of calcium and magnesium that are found in Urdari lake can be explained by the contact of the water with the possible remains of marine fauna, sometimes highlighted in the sediments of Oltenia mining basin.

The high value of $\mathrm{CBO}_{5}$ indicates the presence of biodegradable organic substances that may reduce the concentration of dissolved oxygen in the water.

The highest exceeding was recorded in the case of phenols (probably resulting from the anaerobic decomposition of wood or from the layer no. X of lignite that comes into direct contact with the water from the lake). Phenols can have a neurotoxic effect on fish but at much higher concentrations then those highlighted by the analyses.

Thus, according to the analyses results, it is found that from a qualitative point of view, the water in the Urdari lake falls into the second quality class, which corresponds to a good ecological status according to Directive 2000/60/EC [22].

The bental (lakebed). The particle size structure of the benthic substrate has a great influence on the selection of organisms from the structure of benthonic cenoses. The substrate of Urdari lake consists of: clays, muds, sands, gravel and boulders (mixed substrate).

Lake sediments, of local and non-local origin, accumulate in the benthic zone. The first ones arise in the lake depression and come from the death of hydrobionts (plants and animals), from their decomposition and from the erosion of the shores, while the non-local ones come from the erosion of the soils within the supply basin brought to Urdari lake by runoff waters. The amount of organic matter in the sediments, in the eu-mesotrophic lakes, is generally high, between 38 and $40 \%$.

\section{Description of the biocenoses}

Urdari lake can be included in the category of eu-mesotrophic lakes, with a maximum depth of $20 \mathrm{~m}$, the water is rich in biogenic nutrients, the thermal is favorable for life in optimal conditions, ensures the development of an abundant phytoplankton and zooplankton, the benthic substrate is rich in organic matter, vegetation and zoobenthos are well developed in the shores area. Water flowering phenomena, due to phytoplankton species, is relatively common (especially in the marshy area).

From the point of view of the identified biocenoses, they are specific to eu-mesotrophic lake (lacustrine) ecosystems (Figure 3), and, subordinated, specific elements of marsh biocenoses, swamp biocenoses and those characteristic to saturated areas (shores in the immediate vicinity of the lake) (Figure 4. a-d). 

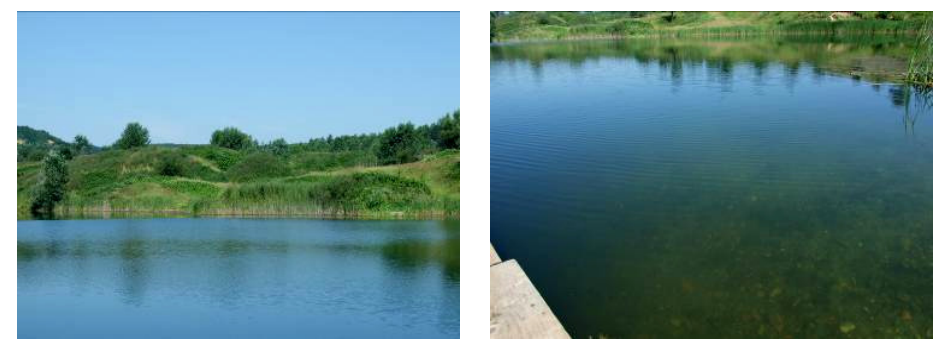

Fig. 3. Lacustine area.

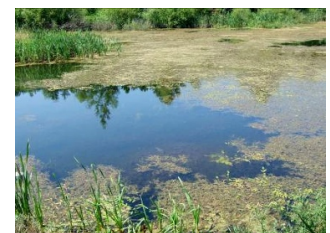

a

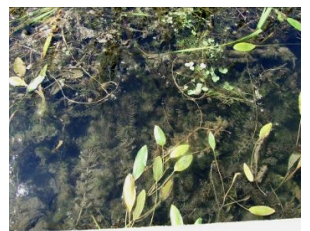

b

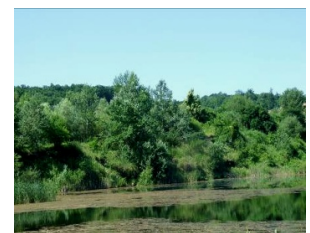

C

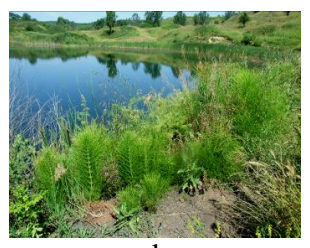

d

Fig. 4. a. Marsh area; b. Swamp area; c. Saturated area (open pit's slopes); d. Saturated area (inner dump's slopes).

Lacustrine area. It is the most important in terms of the area occupied and implicitly in terms of populations and the number of individuals represented.

In lakes, life is represented by numerous populations of plants and animals grouped in biocenoses. Inside biocenoses, plant and animal associations acquire characteristic aspects depending on the conditions offered by the biotope. Pelagial (pelagic) and bental (benthic zone) are populated by pelagos and benthos.

\subsection{Pelagos (Pelagic organisms)}

It consists of associations of vegetal and animal organisms in the water mass. The characteristics of the pelagos are the neuston, plankton and necton.

The Neuston is a biocenosis present on the calm surface of water. Neuston consists of phytoneuston, zooneuston and bacterioneuston. Phytonuston is represented by the primary producers. Its structure contains microscopic algae and larger plants with partially emerged bodies (Salvinia natans, Lemna sp., etc.), which float on the surface of the water. They are populated mainly on the parts in the water with numerous coelenterates, worms, mollusks, crustaceans and insect larvae. Zooneuston is represented by consumers of different orders consisting of invertebrate animal organisms, generally small or very small. Bacterioneuston is represented by decomposers, consisting of bacteria that are associated with microscopic fungi [18].

Within the neuston, according to the place and the way in which the organisms carry out their activity, we can differentiate the epineuston and the hyponeuston. Epineuston is made up of populations of plants (epiphytoneuston) and animals (epizooneuston) that appear at the surface of the water film using it as a support and living environment. All the populations here are aerobionts. The hyponeuston is made up of populations of plants (microscopic algae) and animals, which work in the thickness of the water film and on its lower face, using it as a substrate for support or movement. All the populations here are hydrobionts. The hyponeuston, according to the populations that form it, is differentiated into euhiponeuston and merohypononeuston $[18,19]$.

The Plankton is a biocenosis present in all lacustrine ecosystems. It consists of phytoplankton, zooplankton and bacterioplankton. In the water mass, regardless of the functional ecological group, there are holoplanktonic or permanent organisms characteristic 
of this biotope and meroplanktonic or temporary organisms that spend part of their life on the benthic substrate.

The Phytoplankton is composed almost exclusively of algae. It is spread in the euphotic area of the basin (the layer of illuminated water). Phytoplankton is composed of species of siliceous algae (diatoms), blue-green algae (cyanophyceae) and green algae (chlorophylls) [18]. The phenomenon of excessive multiplication of some algae is known as water flowering, it is caused by a single species of algae, namely that species for which living conditions become optimal. This phenomenon determines the change of the biological balance in plankton and implicitly in the ecosystem.

The zooplankton is poor in species but very rich in individuals, being composed of animal species belonging to the following groups: Protozoa (rhizopods, flagellates and ciliate), Vermes (especially rotifers), Arthropoda (crustaceans: cladocers and copepods) $[18,19]$.

The Necton, an association of different species of animals, actively swiming throughout the body of water. True necton is formed by fish. However, other groups of animals occupying this biotope may be included here, but they are less important. Among these we mention adult aquatic insects or insect larvae, some crustaceans, turtles, etc.

The fish found in Urdari lake are represented by: Cyprinus carpio, Carassius carassius, Carrassius gibelio, Abramis brama danubii, Rutilus rutilus, Tinca tinca, Scardinus erythrophthalmus, Leucaspius delineatus, Perca fluviatilis, Esox lucius and Silurus glanis.

It should be noted that these fish species were introduced by humans, but without a massive population of the lake (as is practiced in lakes intended for fishfarming or competitive sport fishing).

The food of the juvenile fish is represented by plankton organisms. The food of adult fish is diverse, many species having an omnivorous nutrition (Cyprinus carpio, Carassius $s p$., etc.), other species are carnivorous (Perca fluviatilis, Esox lucius and Silurus glanis) or vegetarian (Leucaspius delineatus). The juvenile fish and the plankton-consuming adult fish (planktonophages) form an important link in the trophic chains in the lake basins, in fact, representing the link that capitalizes the plankton (so that in turn they are eaten by other fish or predators).

\subsection{Benthos (Benthic organisms)}

It consists of associations of organisms (plants, animals, microorganisms) that populate the bottom of the lake basin. Corresponding to the two littoral and deep areas, there is a littoral benthos and a deep benthos. The structure of the benthos in these two areas is different both qualitatively and quantitatively [18].

In the littoral area, the benthos is populated by numerous species of plants (phytobenthos), animals (zoobenthos), bacteria and microscopic fungi (with a role in the decomposition of dead plants and animals). In the deep area, the benthos lacks photosynthetic plants due to the absence of light (zoobenthic associations receive food from the photic zone of the pelagic consisting of detritus or dead plants and animals) [19].

The Phytobenthos is well represented in the littoral zone and is missing in the deep zone. Its composition includes large plants (macrophytes) and small plants (microphytes).

Macrophytobenthos is a permanent but not exclusive component of the littoral area of lakes. Upon contact of water with the land, the benthos supports the reed belt, formed of species belonging to the genera Typha, Scirpus, Juncus, Phragmites, Carex, Glyceria, Hippuris, Eleocharis, Symphytum, Equisetum, etc. The populations of these plants have only the base of the stem in the water. In the area of the reed belt on shallow water surfaces, numerous plant populations develop, fixed by muddy bottoms. The stem is deeply submerged in water, and the flowers and most of the leaves are on top. The most common 
are Alisma plantago aquatica, Sagittaria sagittifolia, Lythrum salicaria, Cicuta virosa, etc. Where the depth increases, macrophytes with floating leaves fixed to the substrate by roots, such as Potamogeton natans, Trapa natans, Ranunculus aquatilis, etc. emerge.

In the deeper parts of the coast and in some shallower places are submerged macrophytes, which create true underwater meadows, the most important being represented by Myriophyllum sp., Potamogeton sp.

The Microphytobenthos consists of all unicellular colonial and multicellular plant organisms of microscopic dimensions that live on the muddy and sandy bottom.

The Periphyton is made up of all the vegetal and inferior animal organisms that live fixed on macrophytes, on boulders, gravel, etc. (sponges, bryozoans, hydras, etc.).

The ecological role of the phytobenthos. Phytobenthos has a particularly important role in the processes that take place in the ecosystem. Phytobenthos is primarily an important producer of organic matter and is a source of food for phytophagous animals. Many algae serve as biological indicators of the degree of saprobity of the lake basin $[7,8]$.

The Zoobenthos is made up of all animal organisms whose living environment is represented by mud, sand, etc. or the surface of these substrates.

The zoobenthos from the littoral area has in its structure numerous species of shells, snails, worms, insect larvae, crustaceans, bryozoans, protozoa. Dominant are insect larvae and mollusks $[9,18,19]$.

In the deep zone, the zoobenthos has a different composition. Here live populations of protozoa, sponges, bryozoans, different worms (rotifers, nematodes, annelids, flatworms). Each facies, clayey, sandy, muddy-sandy, stony or muddy, organic, resulting from organic deposits, etc. favors the formation of a characteristic structure of the biocenosis $[8,9]$.

\subsection{Other animal organisms integrated in the biocenotic structure of the lacustrine ecosystem}

Phytophilic fauna. On the stems and leaves of macrophytes are numerous populations of animals that crawl slowly in search of food (snails, insect larvae, worms, etc.).

On the underside of floating leaves are interesting animal associations, including larvae of chironomids, colonies of bryozoans, planarians and snails. Also on the underside of the floating leaves are frequently found gelatinous piles of water snail eggs, dragonfly eggs, brown Glossosiphonia cocoons and butterfly larvae.

Numerous populations of invertebrates and vertebrates live on the aerial side of macrophyte stems and in the reed thicket.

Various species of amphibians live on the shores of the lake and in the reeds of the littoral area. Some of them, such as newts and salamanders, are aquatic only during the breeding season (March - June), but others, frogs, are permanently aquatic (Bombina variegate, Bombina bombina, Rana esculenta and Rana ridibunda, etc.). They feed on insects but also attack juvenile fish. Some of the adult frogs and their larvae are eaten by storks, herons, kites, water snakes. Aquatic reptiles are represented by Emys orbicularis, Natrix tessellata and Natrix natrix.

In the reeds, in the willows, poplars or anines on the lake shore and in the high shores represented by the final slopes of the open pit, nest numerous species of birds that procure their food from the water: Anas plathyrhynchos, Fulica atra, occasionally Cygnus olor etc.

A few water mammals also live in the reed thicket. Some of them are rodents, others are carnivores. Among these we mention the otter (Lutra lutra). 


\section{Functionality and dynamics}

The morpho-physiographic structure of the lake basin, the geological substrate, the surface, the depth, the altitude, the latitude, the physico-chemical properties of water, the climate, the currents, the deposition/erosion processes have a great influence on the life in the lakes. The quality of biocenoses, their structure, is determined by the quality of the abiotic factors and the properties of the biotope. The biotope acts as a mechanism of natural selection, favoring the installation of some species and preventing the penetration of others.

Through their activity, biocenoses influence the general appearance of the biotope and substantially change its quality through the activity carried out within a year. The modifications of the physical and chemical properties of the biotope are the consequence of the activity of the biocenoses. There is an interdependence between the biotope and the biocenosis, the interrelationships are close and the influences are mutual. Their ensemble is reflected in the concrete physiognomy of the ecosystem $[8,9,18,19]$.

In the structure of the lacustrine ecosystem that characterizes Urdari lake, as in any other ecosystem, four main constituents are distinguished: abiotic substances; producers; consumers and decomposers $[18,19]$.

Plants, regardless of their size (micro or macrophytes), are the only ones able to transform inorganic matter (minerals, water, $\mathrm{CO}_{2}$ ) into organic matter, using solar energy in this complex process. The life of all animals in lakes depends directly or indirectly on the existence and physiological activity of plants. The organic matter synthesized by plants and the accumulated energy acquire new meanings and valences through their circulation in the ecosystem. Everything is based on a general scheme in the sense that each species through its individuals "becomes a link in the mechanism of circulation and transformation of substances and energy in the biocenoses and ecosystem" [18] (Figure 5).

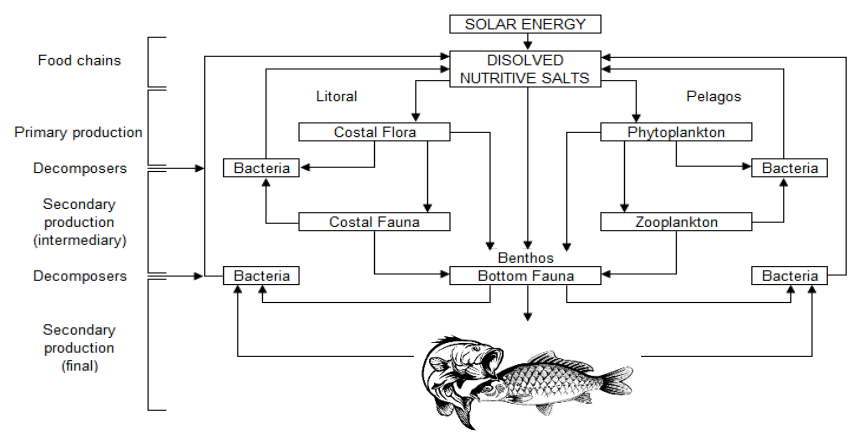

Fig. 5. Nutrient pathways in lakes (after Pârvu [18]).

The food chains contain 3-5 links, less often they reach 8-10. They start with the smallest plants and end with the largest animals such as fish, crustaceans, birds, mammals. Microscopic algae are capitalized by nutrition by phytophagous animals, and they are consumed by primary carnivorous animals, followed by secondary ones that succeed each other in several trophic links, the latter being formed by tertiary carnivorous animals. Macrophytes are also integrated in food chains, being consumed by phytophagous animals, and these in turn fall prey to carnivorous animals [18].

The organic remains of plants, dead plants and animals enter in the sphere of activity of decomposers, which turn them into chemical elements and substances. These reenter in the cycle and create the possibility of continuing life in the ecosystem [7-9, 19].

Over time, the morphological state of the lake basins changes, appearing the irreversible transformation of the lake into a marsh, swamp and land. The process of organic clogging takes place permanently in two ways $[8,18]$ : 
- deposits on the bottom of the lake, especially in the littoral area, which facilitates the advance of the shore inside the lake, reducing its surface and depth;

- the formation over the water mirror of a shore plaur that gradually advances, occupying and clogging the lakes as a result of organic depositions.

\section{Conclusions}

Leaving aside the formation of Urdari lake (in the remaining gap of a former lignite openpit), following the results of the research, we can say that it is at present and evolves similarly to the eu-mesotrophic natural lakes located in different hilly and plain areas in Romania.

The ecological conditions from around Urdari lake have favored the installation of an important vegetation in which we can find phytocoenoses with a conservative value, as well as a diverse fauna.

The next step is to make a complete inventory of the phytocoenoses present in the area, based on the principles of the Central European phytocenological school.

Taking into account the phytocoenotic diversity, the characteristic avifauna and ichtyofauna, it is necessary to elaborate an adequate management plan, which will carefully monitor human interventions (especially those that may endanger the originality and integrity of this habitat). Also, we recommend continuous monitoring of the vegetation in the studied area, in order to complete the inventory with phytocoenoses whose emergence is related to natural multi-annual dynamics as well as human interventions.

\section{References}

1. I.M. Apostu, M. Lazăr, F. Faur, Sustainability 13 (12), 6919 (2021)

2. R.G. Doupé, A.J. Lymbery, Mine Water Environ. 24, 134-138 (2005)

3. M. Schultze, K.H. Pokrandt, W. Hille, Limn. Ecol. Manag. Inland Waters 40, 148-155 (2010)

4. L. Žižka, J. Burda, Brown Coal Bulletin 3, 11-46 (2020)

5. A. Bajcar, J. Szczepiński, B. Rogosz, M. Resak, K. Piróg, Brown Coal Bulletin 3, 79-87 (2020)

6. I.M. Apostu, M. Lazăr, F. Faur, 3rd International Scientific and Technical Conference "Innovative Development of Resource-Saving Technologies and Sustainable Use of Natural Resources", 38-41 (2020)

7. A. Neacşu, G.G. Arsene, A. Fărcăşescu, F. Faur, C. Stroia, Res. Jour. of Agri. Sci. 40 (3), 55-60 (2008)

8. A. Neacşu, G.G. Arsene, A. Fărcășecu, F. Faur, Res. Jour. of Agri. Sci. 41 (2), 279-284 (2009)

9. A. Neacşu, G.G. Arsene, F. Faur, A. Nicolin, I. Imbrea. Res. Jour. of Agri. Sci. 47 (2), 116-129 (2015)

10. M. Lazăr, F. Faur, Mining Revue 18 (2), 18-22 (2012)

11. M.L. Blanchette, M.A. Lund, Curr. Opin. Environ. Sustain. 23, 28-34 (2016)

12. I.M. Apostu, M. Lazăr, Res. Jour. of Agri. Sci. 49 (4), 9-19 (2017)

13. I.M. Apostu, A. Florea, Res. Jour. of Agri. Sci. 50 (4), 28-39 (2018)

14. C.D. McCullough, M. Schultze, J.A. Vandenberg, Minerals 10 (2), 133 (2020)

15. A. Maest, R. Prucha, C. Wobus, Minerals 10 (8), 727 (2020)

16. M.A. Dodoacă, Ecological rehabilitation of the remaining gap of Urdari open-pit (in Romanian). Project for Bachelor of Engineering, Petroşani (2010).

17. E. Huidu, O. Scorțariu, Oltenia mining monography (in Romanian), Vol. IV, (Măiastra PH, Târgu-Jiu, 2008)

18. C. Pârvu, General Ecology (in Romanian) (Technical PH, Bucharest, 2001)

19. I. Dumitrescu, General Ecology (in Romanian) (Universitas PH, Petrosani, 2003)

20. SR EN ISO 5667-1 (2007)

21. Ministry of Environment and Water Management, Order no. 161 (2006)

22. Directive 2000/60/EC (2000) 